\title{
Enzyme immunoassay for the detection of porcine gelatine in edible bird's nests
}

\begin{abstract}
Porcine gelatine is a common adulterant found in edible birdôs nests (EBNs) used to increase the net weight prior to sale. This study aimed to develop indirect enzyme-linked immunosorbent assays (ELISAs) for porcine gelatine adulteration using anti-peptide polyclonal antibodies. Three indirect ELISAs were developed (PAB1, 2 and 3), which had limits of detection (LODs) of $0.12,0.10$ and $0.11 \mu \mathrm{g}$ gï 1, respectively. When applied to standard solutions of porcine gelatine, the inter- and intra-assays showed coefficients of variation (CVs) less than $20 \%$ and were able to detect at least $0.5 \mathrm{ng} \mu \mathrm{gi} 1(0.05 \%)$ porcine gelatine in spiked samples. The proposed ELISA offers attractions for quality control in the EBN industry.
\end{abstract}

Keyword: Edible bird's nest; Gelatine; Adulterant; ELISA 